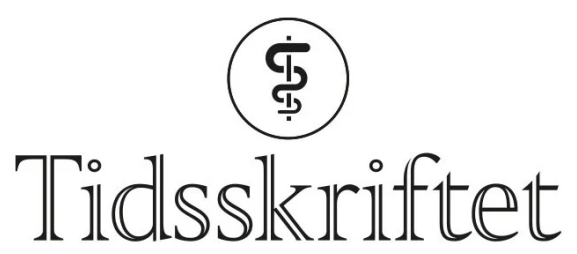

DEN NORSKE LEGEFORENING

\title{
Misbruk av pregabalin
}

\author{
BREV TIL REDAKTØREN
}

JØRGEN G. BRAMNESS

Senter for rus og avhengighetsforskning (SERAF)

Universitetet i Oslo

GABA-analogen pregabalin har vist seg å ha både antiepileptiske (1) , anxiolytiske (2) og analgetiske effekter (3), selv om aspekter ved det siste nylig har vært diskutert i Tidsskriftet $\mathrm{nr} .10 / 2010$ (4). Disse egenskapene synes ut fra prekliniske undersøkelser ikke å skyldes stimulering av $\mathrm{GABA}_{\mathrm{A}}$-reseptorkomplekset, men snarere en presynaptisk binding til $\alpha_{2} \delta$ subenheten av spenningsavhengige $\mathrm{Ca}^{2+}$-kanaler. Dette skulle gi en dempende effekt uten de GABA-erge midlers misbruks- og avhengighetsproblematikk. Midlet ble imidlertid tidlig overvåket av både de europeiske og amerikanske legemiddelmyndigheter med tanke på misbruk. Chalabianloo \& Schjøtt konkluderte i Tidsskriftet i 2009 (5) med «at pregabalin sannsynligvis hadde lavere avhengighets- og misbrukspotensial enn tradisjonelle rusmidler ...», men mye tyder på at misbrukspotensialet til pregabalin ikke er godt nok undersøkt (므). Nå foreligger to publikasjoner der man peker på at pregabalin kan misbrukes.

I en kasusbeskrivelse i American Journal of Psychiatry beskrives en 47 år gammel mann som oppfylte DSM-kriteriene for avhengighet (7.) og i en gjennomgang av spontanrapportert misbruk eller avhengighet til de svenske legemiddelmyndighetene i perioden 1980-2009 fant forskerne at 16 av 198 rapporter omhandlet pregabalin, hvilket forfatterne anser som et tydelig signal på at pregabalin kan være forbundet med misbruk (모). En ny medisins misbrukspotensial er ofte vanskelig å undersøke i kontrollerte studier utført på et lite antall, sterkt selekterte pasienter som følges nøye opp (9.). I tidlige faser må vi derfor anvende spontanrapportering for å identifisere misbruk og avhengighet. I lys av dette er disse to tidlige publikasjonene interessante og gir oss grunn til fortsatt å holde øye med pregabalin.

\section{LITTERATUR}

1. LaRoche S. A new look at the second-generation antiepileptic drugs: a decade of experience. Neurologist 2007; 13: 133-9.

2. Mula M, Pini S, Cassano G. The role of anticonvulsant drugs in anxiety disorders: a critical review of the evidence. J Clin Psychopharmacol 2007; 27: 263-72.

3. Jensen T, Finnerup N. Management of neuropathic pain. Curr Opin Support Palliat Care 2007; 1: 126-31. 
4. Holtedahl R. Tvilsom dokumentasjon av effekten av pregabalin ved fibromyalgi. Tidsskr Nor Legeforen 2010; 130: 1032-6.

5. Chalabianloo F, Schjott J. Pregabalin og misbrukspotensial. Tidsskr Nor Legeforen 2009; 129: 186-7.

6. Bramness JG, Sandvik P, Engeland A et al. Does pregabalin (Lyrica((R))) help patients reduce their use of benzodiazepines? A comparison with gabapentin using the Norwegian Prescription Database. Basic Clin Pharmacol Toxicol 2010; e-publisert 23.4.

7. Grosshans M, Mutschler J, Hermann D et al. Pregabalin abuse, dependence, and withdrawal: a case report. Am J Psychiatry 2010; 167: 869.

8. Schwan S, Sundstrom A, Stjernberg E. A signal for an abuse liability for pregabalin-results from the Swedish spontaneous adverse drug reaction reporting system. Eur J Clin Pharmacol 2010; 66: 947-53.

9. Bramness J, Buajordet I, Skurtveit S. The role of pharmacoepidemiological studies in the market withdrawal of carisoprodol (Somadril@) in Europe. Nor J Epidemiol 20o8; 18: 167-72.

Publisert: 9. september 2010. Tidsskr Nor Legeforen. DOI: 10.4045/tidsskr.10.0834

(C) Tidsskrift for Den norske legeforening 2023. Lastet ned fra tidsskriftet.no 26. april 2023. 